\title{
Characterization and Catalytic Activity of Free and Immobilized Lipase from Aspergillus niger: a Comparative Study
}

\author{
Vania C. F. da Silva, Fabiano J. Contesini and Patrícia de O. Carvalho* \\ Curso de Farmácia, Universidade São Francisco, Av. São Francisco de Assis, 218, \\ 12916-900 Bragança Paulista-SP, Brazil
}

\begin{abstract}
Lipase de Aspergillus niger foi imobilizada por deposição utilizando Celite e as atividades de hidrólise e esterificação, a estabilidade e a enantioseletividade das formas livre e imobilizada foram comparadas. Ambas as preparações mostraram propriedades bioquímicas similares, com atividade máxima em pH 6,0 e temperatura de $30-40{ }^{\circ} \mathrm{C}$. Não foram observadas diferenças na atividade hidrolítica em função do $\mathrm{pH}$ para as duas formas da enzima. Os efeitos mais importantes observados após a imobilização foram a estabilidade térmica e a melhoria da atividade de esterificação na reação do $(R, S)$-ibuprofeno com 1-propanol em presença do isooctano. Além disso, a lipase na forma imobilizada manteve, pelo menos, $73 \%$ de sua atividade de esterificação após 5 dias de armazenamento a $40^{\circ} \mathrm{C}$ e pôde ser reciclada e reutilizada por pelo menos 6 vezes.
\end{abstract}

Aspergillus niger lipase was immobilized by deposition on Celite and the hydrolytic and esterification activities, stability and enantioselectivity of both free and immobilized enzyme were compared. Both the free and immobilized preparations showed similar biochemical properties, with maximum activity at $\mathrm{pH} 6.0$ and a temperature of $30-40{ }^{\circ} \mathrm{C}$. The most important effects observed when the lipase was immobilized were thermal stability and an improved esterification activity during the reaction of $(R, S)$-ibuprofen with 1-propanol in isooctane. Moreover, immobilized Aspergillus niger lipase maintained an esterification activity of at least $73 \%$ after 5 days of storage at $40{ }^{\circ} \mathrm{C}$ and can be recycled and reused at least 6 times.

Keywords: immobilization, lipase, ibuprofen

\section{Introduction}

Lipases (triacylglycerol hydrolases, EC 3.1.1.3) have the natural catalytic function of hydrolyzing fatty acid ester bonds in water and are the most commonly used enzymes in organic synthesis, mainly due to their property of catalyzing the resolution of racemic drugs such as $(R, S)$-ibuprofen [2-(4-isobutylphenyl) propionic acid]. ${ }^{1,2}$ The enantiomeric differentiation of lipases is used to separate racemic mixtures of chiral esters, hydrolyzing preferentially one enantiomer or through esterification reactions of chiral acids and/or chiral alcohols. The versatility of these biocatalysts, when used in organic solvents, allows attainment of a great variety of other pharmaceutical intermediates. ${ }^{3,4}$ Each application requires specific properties of the lipases with respect to substrate specificity, stability, temperature and $\mathrm{pH}$-dependence. Filamentous fungi are the most preferred sources of lipases as they might produce extracellular enzymes, facilitating

*e-mail: patcarvalho@saofrancisco.edu.br extraction from fermentation growth media. The most productive species belong to the genera Rhizopus, Rhizoтисоr, Mucor, Geotrichum, Aspergillus and Penicillium. ${ }^{5}$

In previous study, we described a lipase produced in our laboratory from Aspergillus niger, which provided the best results, in terms of enantioselectivity, for the resolution of racemic substrates when compared with other native lipases. ${ }^{6,7}$ In these studies, experiments were performed using the crude lyophilized extract of the free enzyme, which requires the production of large amounts of enzymes for each set of assays, making the process laborious and expensive. To reach better performance an alternative approach involve enzyme entrapment which has the main advantage of using immobilized enzymes as biocatalysts which turns possible the development of continuous processes, since the enzyme can easily be recovered, thereby making the process economically feasible. Furthermore, it is also possible to increase the stability of the biocatalyst and reduce operational costs of industrial processes by the selection of an appropriate immobilization 
method. The immobilization techniques utilize adsorption, linkage of the enzyme to an insoluble material, entrapment of enzyme into polymeric gels or encapsulation. Adsorption on matrices such as Celite was selected due to its chemical inertness, unique interconnected pore structure, low price and the possibility of enhancing reaction rates by providing a better distribution of the catalyst. ${ }^{8}$

The aim of this study was to compare the hydrolytic and esterification activities, biochemical properties and stability of free and immobilized lipase from Aspergillus niger. In addition, the ability of this lipase, immobilized on Celite, to resolve $(R, S)$-ibuprofen enantiomers by an esterification reaction with 1-propanol in isooctane was evaluated.

\section{Experimental}

\section{Chemicals}

Isooctane, 1-propanol, $(R, S)$-ibuprofen and pure enantiomers were purchased from Sigma-Aldrich Chemical Co. (St. Louis, MO, USA). Yeast extract and Bacto peptone were purchased from Difco Laboratories, (Detroit, MI, USA). The components for culture media, Celite, chemical reagents and the other solvents were obtained from Merck (Darmstadt, Germany) and from Sigma-Aldrich Chemical Co. in the highest purity available. Low acidity olive oil (Carbonel) was purchased at a local supermarket.

\section{Lipases}

The lipases were produced in a basal medium with an initial $\mathrm{pH}$ value of 6.0 and consisted of $2 \%(\mathrm{~m} / \mathrm{v})$ peptone, $0.5 \%(\mathrm{~m} / \mathrm{v})$ yeast extract, $0.1 \%(\mathrm{~m} / \mathrm{v}) \mathrm{NaNO}_{3}, 0.1 \%(\mathrm{~m} / \mathrm{v})$ $\mathrm{KH}_{2} \mathrm{PO}_{4}, 0.05 \%(\mathrm{~m} / \mathrm{v}) \mathrm{MgSO}_{4} \cdot 7 \mathrm{H}_{2} \mathrm{O}$ and $2 \%(\mathrm{~m} / \mathrm{v})$ olive oil. Cultures were grown in Erlenmeyer flasks $(500 \mathrm{~mL})$ containing $120 \mathrm{~mL}$ of the growth medium. The cultures were inoculated with $1 \mathrm{~mL}$ of spore suspension $\left(10^{5}-10^{6}\right.$ spores $\left.\mathrm{mL}^{-1}\right)$ and the flasks were stirred on an orbital shaker $(130 \mathrm{rpm})$ at $35^{\circ} \mathrm{C}$ for $72 \mathrm{~h}$. After this period, the cultures were filtered and the supernatants were treated with ammonium sulphate ( $80 \%$ saturation). The precipitates were dialyzed in water and lyophilized for use as an extracellular crude lipase preparation in powder form. The residual water in the lyophilized lipases was $0.2-0.3 \%(\mathrm{~m} / \mathrm{m})$.

\section{Immobilization of lipases}

The crude lipases $(0.1 \mathrm{~g}$, corresponding to $58 \mathrm{mg}$ protein) were dissolved in $5 \mathrm{~mL}$ sodium phosphate buffer $\left(50 \mathrm{mmol} \mathrm{L}^{-1}, \mathrm{pH} 7.5\right)$ and mixed with Celite $(500 \mathrm{mg})$ for $20 \mathrm{~min}$. The preparation was then lyophilized.

\section{Enzymatic assays}

The hydrolytic activities of the free or immobilized lipases were determined by the titration of free fatty acids with $0.05 \mathrm{~mol} \mathrm{~L}^{-1} \mathrm{KOH}$ released from olive oil hydrolysis. ${ }^{9}$ The enzymatic activity was expressed as $\mu$ mol of oleic acid released per minute of reaction $\left(\mu \mathrm{mol} \mathrm{min} \mathrm{m}^{-1}\right)$. The amount of protein was determined by the Lowry methodology ${ }^{10}$ using egg albumin as standard and measuring the absorbance at $280 \mathrm{~nm}$.

\section{Characterization of free and immobilized lipases}

The hydrolytic activities of the lipases were determined at different $\mathrm{pH}$ values (citric buffer, $\mathrm{pH}$ 4-6; phosphate buffer, pH 7-8; glycine buffer, $\mathrm{pH}$ 9-10) and temperatures (in the range between 10 and $60^{\circ} \mathrm{C}$ ). Hydrolytic enzyme was analyzed for temperature stability in the range of 20 and $60^{\circ} \mathrm{C}$, and $\mathrm{pH}$ stability was determined in the range of 4.0-10.0. For determination of temperature stability, lipases were pre-incubated for $12 \mathrm{~h}$ in $\mathrm{pH} 7.0$ of phosphate buffer. The effect of $\mathrm{pH}$ on lipases stability was analyzed after the pre-incubation of lipases in $0.1 \mathrm{~mol} \mathrm{~L}^{-1}$ buffer (citric buffer, pH 3-6; phosphate buffer, pH 7-8; glycine buffer, pH 9-10) at $4{ }^{\circ} \mathrm{C}$ for $12 \mathrm{~h}$. Residual hydrolytic activity was measured using the titration method described above.

\section{Esterification reaction}

The standard reaction mixture was composed of $(R, S)$ ibuprofen (66 mmol L $\mathrm{m}^{-1}$ ) 1-propanol $\left(66 \mathrm{mmol} \mathrm{L}^{-1}\right)$ and isooctane $(10 \mathrm{~mL})$ without addition of water. The reaction was started by the addition of $40 \mathrm{mg}$ free lipases or $0.24 \mathrm{~g}$ of immobilized lipases (corresponding to $0.04 \mathrm{~g}$ of enzyme and $0.20 \mathrm{~g}$ of Celite) and carried out in a sealed Erlenmeyer's on a shaker with orbital magnetic stirring at $180 \mathrm{rpm}$, at $35{ }^{\circ} \mathrm{C}$. Experiments without the addition of the enzyme were carried out to evaluate the spontaneous esterification percentage of the system. Samples of $100 \mu \mathrm{L}$ of the solution were withdrawn at different times and diluted in $1.4 \mathrm{~mL}$ isooctane. The amount of ester (conversion degree) formed during the reaction and the enantiomeric excess of the $(S)$ ibuprofen were determined by gas chromatography (GC) and by high performance liquid chromatography (HPLC), respectively.

\section{Chromatography analysis}

Gas chromatography was performed using a Chrompack CP 9001 system equipped with a flame ionization detector (FID) and a CP-Sil $5 \mathrm{CB}$ column $(10 \mathrm{~m} \times 0.25 \mathrm{~mm} \times$ 
$0.12 \mu \mathrm{m})$. Injector temperature was $300^{\circ} \mathrm{C}$ and the detector was $350^{\circ} \mathrm{C}$; oven temperature was maintained at $180^{\circ} \mathrm{C}$. Carrier gas was hydrogen with a flow of $1.0 \mathrm{~mL} \mathrm{~min}^{-1}$. An external standard method was employed to quantify the ester formed and the remaining acid. The enantiomers of the unreacted ibuprofen were separated by HPLC using a chiral column (Chiralcel OD, Daicel Chemical Industries, Ltd., Japan). The mobile phase was a mixture of $n$-hexane/ isopropanol/trifluoracetic acid (HPLC grade) (100/1/0.1,

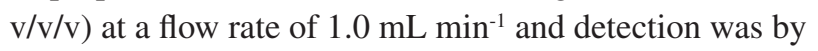
$\mathrm{UV}$ at $254 \mathrm{~nm}$.

\section{Enantioselectivity-value measurements}

The value of enantioselectivity (E-value) was calculated from the enantiomeric excess of the remaining $(S)$-ibuprofen (ee) and the conversion degree (c), according to the method described by Chen et al. ${ }^{11}$ (equation 1 ).

$$
E=\frac{\ln \left[(1-c)\left(1-e e_{s}\right)\right]}{\ln \left[(1-c)\left(1+e e_{s}\right)\right]}
$$

\section{Results and Discussion}

\section{Screening of native lipases}

The evaluation of lipases during olive oil hydrolysis in aqueous medium as well as the evaluation of esterification activity in organic medium was carried out using free and immobilized lipases (Table 1). All the assays were performed in triplicate.

The highest specific hydrolytic activity $\left(0.71 \mathrm{U} \mathrm{mg}^{-1}\right)$ and esterification activity (26\%) were obtained from immobilized Aspergillus oryzae and Aspergillus niger lipases, respectively. Lipases from A. terreus and A. flavus demonstrated lower performances, attaining maximum esterification activities of $4.8 \%$ and $13.4 \%$, respectively, after immobilization. The most important effect observed was the improvement in esterification activity (1.3-1.8 fold) when the enzymes were immobilized. Interestingly, the immobilized lipase from Aspergillus oryzae was active in the esterification of $(R, S)$-ibuprofen $(3.7 \%)$, but not in the free form, under the used conditions. Many studies have shown that immobilized lipases have higher activity than their free forms, ${ }^{12,13}$ a result that was also obtained in the present study. Aspergillus niger immobilized lipase was able to synthesize $26 \%$ yield of the ester of ibuprofen, approximately 1.8 -fold higher yield than when the free enzyme was used (14.6\%). In addition, no correspondence was found between the hydrolytic activities of each lipase tested and their performance to synthesize ibuprofen ester. Based on these results, Aspergillus niger lipase was selected and used in both free and immobilized form in all subsequent experiments.

Effect of $\mathrm{pH}$ and temperature on the hydrolytic activities of free and immobilized lipase

The activity profiles of the free and immobilized lipases at $\mathrm{pH} 4$ to 10 and at temperatures ranging from 10 to $55^{\circ} \mathrm{C}$ were measured. Figures 1 and 2 present the data used for the determination of optimal $\mathrm{pH}$ and temperature.

The hydrolytic activity of the free and immobilized preparations is highest in the range of $\mathrm{pH} 6.0$ to 6.5 . No differences were observed in the effect of $\mathrm{pH}$ for both free and immobilized lipases; however, the temperature effect on activity was different for both preparations. The most favorable temperature for the immobilized preparation was $40^{\circ} \mathrm{C}$, whilst for the free lipase, the enzyme was most active at $30-35^{\circ} \mathrm{C}$. Complete denaturation for both lipase preparations occurred at $60^{\circ} \mathrm{C}$.

Table 1. Influence of immobilization on hydrolytic and esterification activities of lipases from Aspergillus strains

\begin{tabular}{|c|c|c|c|}
\hline Sources of lipases & & Specific hydrolytic activity ${ }^{a} /\left(\mathrm{U} \mathrm{mg}^{-1}\right)$ & Esterification activity / (\%) \\
\hline \multirow[t]{2}{*}{ Aspergillus flavus } & free & 0.42 & $3.4 \pm 2.4$ \\
\hline & immobilized & 0.45 & $4.8 \pm 2.4$ \\
\hline \multirow[t]{2}{*}{ Aspergillus niger } & free & 0.56 & $14.6 \pm 1.3$ \\
\hline & immobilized & 0.54 & $26.0 \pm 0.8$ \\
\hline \multirow[t]{2}{*}{ Aspergillus oryzae } & free & 0.55 & $\mathrm{ND}^{\mathrm{c}}$ \\
\hline & immobilized & 0.71 & $3.7 \pm 0.9$ \\
\hline \multirow[t]{2}{*}{ Aspergillus terreus } & free & 0.47 & $10.1 \pm 1.4$ \\
\hline & immobilized & 0.51 & $13.4 \pm 1.9$ \\
\hline
\end{tabular}

${ }^{\mathrm{a} S p e c i f i c ~ h y d r o l y t i c ~ a c t i v i t y ~ i n ~} \mathrm{U} \mathrm{mg}^{-1}$ of total protein. One unit $(\mathrm{U})$ is defined as $1 \mu \mathrm{mol}$ of oleic acid released per minute. ${ }^{\mathrm{b}}$ Esterification activity (or conversion degree) is given as the percentage of $(R, S)$-ibuprofen esterified after $72 \mathrm{~h} .^{c}$ Not detected. 


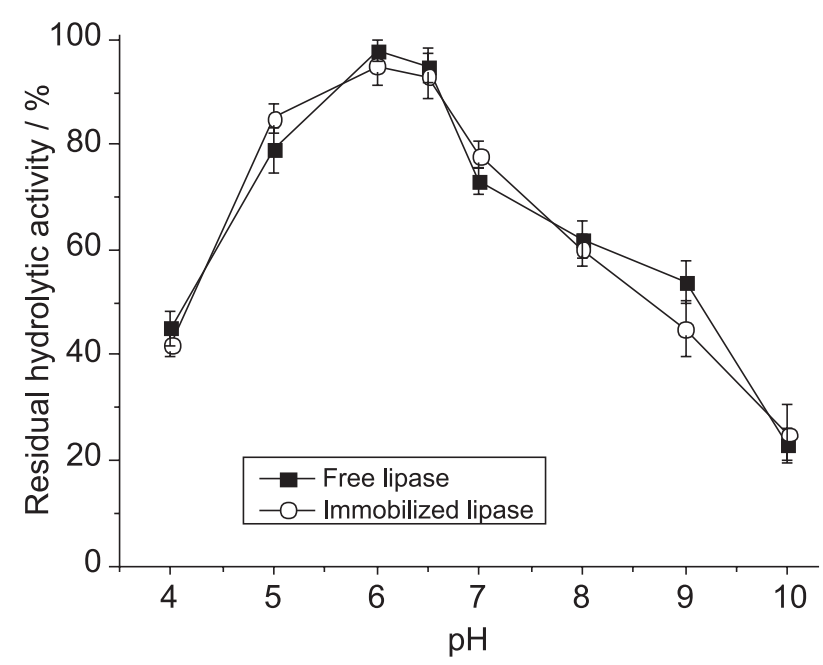

Figure 1. Effect of $\mathrm{pH}$ on the activities of free and immobilized Aspergillus niger lipases.

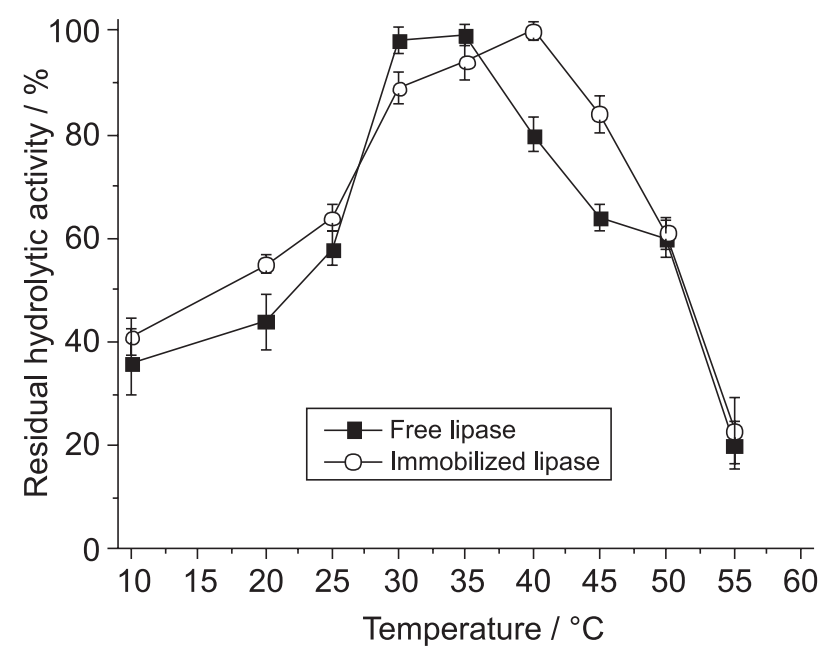

Figure 2. Effect of temperature on the activities of free and immobilized Aspergillus niger lipases.

pH and Thermal stabilities of free and immobilized lipases

To study the $\mathrm{pH}$ and thermal stabilities, the free and immobilized preparations were pre-incubated at $\mathrm{pH} 3-10$ at $4{ }^{\circ} \mathrm{C}$, or at temperature ranging from $25-60{ }^{\circ} \mathrm{C}$ for $12 \mathrm{~h}$, respectively. The obtained results are illustrated in Figures 3 and 4. As expected it was observed some increase on thermostability when using the enzyme in immobilized form.

Free lipase was observed to tolerate a broad range of $\mathrm{pH}$ values (from 5.0 to 8.0 ) and was practically stable between $\mathrm{pH} 5.5$ and 8.0. The immobilized lipase presented a similar behavior, maintaining basically $50 \%$ activity at a $\mathrm{pH}$ of 8.5 .

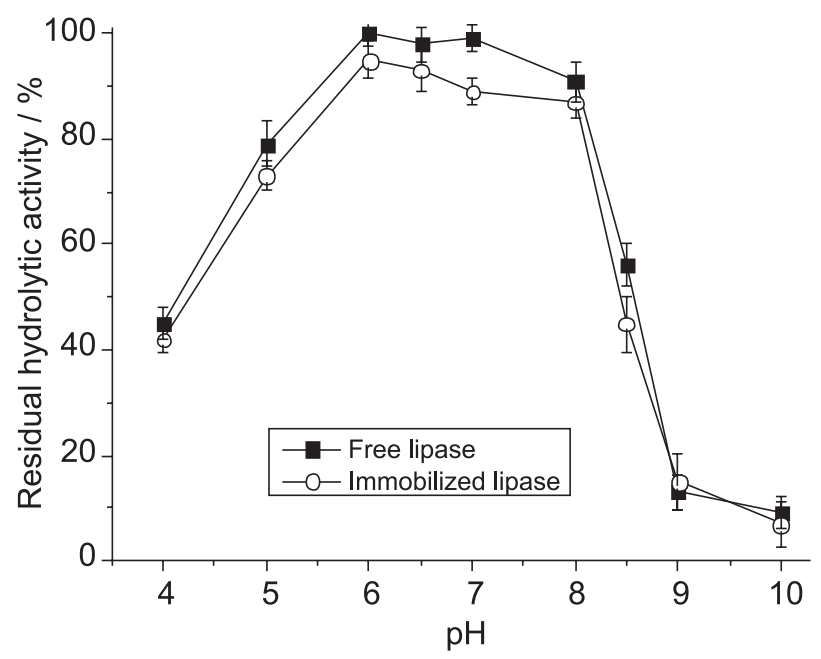

Figure 3. Effect of $\mathrm{pH}$ on the stabilities of free and immobilized Aspergillus niger lipases.

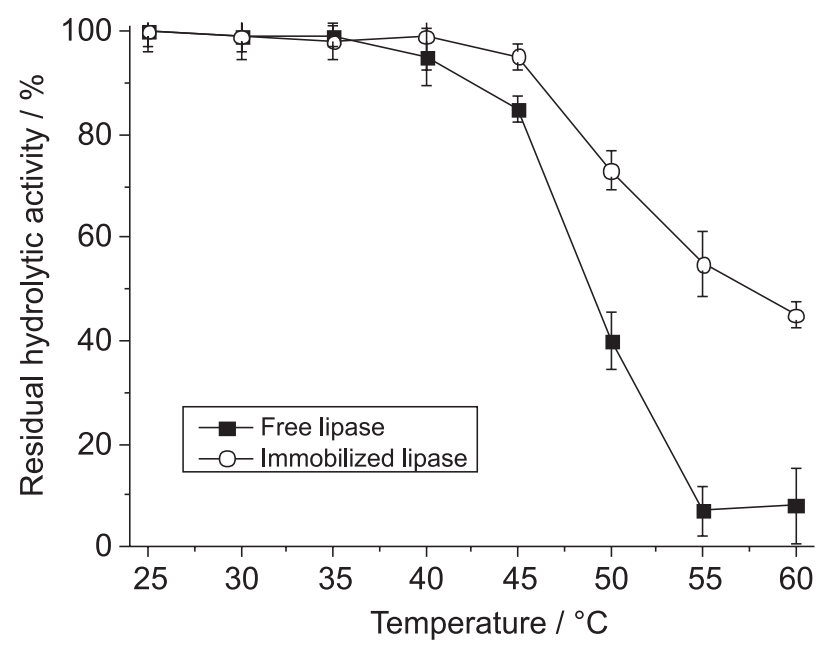

Figure 4. Effect of temperature on the stabilities of free and immobilized Aspergillus niger lipases.

The great majority of fungal lipases presents $\mathrm{pH}$ stabilities in the range of 6.0 to 8.0 and are unstable at $\mathrm{pH}$ values above 8.0. ${ }^{14}$ However, the present finding differs from that observed by Shu et al. ${ }^{15}$ in which Aspergillus niger lipase presented a acidic-resistance and a high $\mathrm{pH}$ stability (2.0-9.0).

The thermal inactivation of the enzymatic preparations showed that free lipase remained stable only up to $40^{\circ} \mathrm{C}$. A considerable decrease in the hydrolytic activity of free lipase was observed at the highest temperatures (above $45{ }^{\circ} \mathrm{C}$ ). On the other hand, inactivation of immobilized lipase occurred at higher temperatures. Immobilized lipase maintained at least $70 \%$ of activity after storage at $50{ }^{\circ} \mathrm{C}$, whilst at $60{ }^{\circ} \mathrm{C}$, the residual activity of the immobilized lipase was $45 \%$ against $8 \%$ for free lipase. 
This result was in agreement with reports in the literature relating that immobilized lipase exhibits higher thermal stability in its activity that exhibited by free lipase, ${ }^{12}$ since immobilized enzymes are known to be more stable in both aqueous and non-aqueous media. ${ }^{16,17}$

\section{Enantioselective esterification for resolution of racemic ibuprofen}

The conversion degree $(c)$, the enantiomeric excess (ee) of remaining acid and the E-values, as a function of time reaction, are shown in Table 2. For free lipase, the conversions were 9.8 and $14.6 \%$, in the range of $24-72 \mathrm{~h}$, with enantiomeric excesses of 4 and $12 \%$ and resulting in $E$-values of 2.1 and 6.9. After $72 \mathrm{~h}$ of the esterification reaction, the rate of propilic ibuprofen ester formation worsened with increased incubation time, due to the gradual formation of water in the reaction that hydrolyses the product.

When the preparation of lipase from A. niger was immobilized, the conversion degree (esterification activity) after $72 \mathrm{~h}$ was $26 \%$, which was almost two-fold higher than that of free lipase (14.6\%). However, the enantiomeric excess of the substrate in the reaction catalyzed by immobilized lipase was only $6 \%$ after $72 \mathrm{~h}$ and the E-value was significantly decreased $(\mathrm{E}=1.5)$.

Table 2. Kinetic resolution of $(R, S)$-ibuprofen catalyzed by free and immobilized Aspergillus niger lipases

\begin{tabular}{lcccccc}
\hline time & \multicolumn{3}{c}{ Free lipase } & \multicolumn{3}{c}{ Immobilized lipase } \\
\cline { 2 - 7 } reaction / h & $c^{\mathrm{a} /(\%)}$ & $e e^{\mathrm{b}} /(\%)$ & $E^{\mathrm{c}}$ & $c /(\%)$ & $e e /(\%)$ & $E$ \\
\hline 12 & 6.4 & $\mathrm{ND}^{\mathrm{d}}$ & $\mathrm{ND}$ & 15.4 & $\mathrm{ND}$ & $\mathrm{ND}$ \\
24 & 9.8 & 4 & 2.1 & 14.7 & $\mathrm{ND}$ & $\mathrm{ND}$ \\
48 & 12.0 & 9 & 5.1 & 17.8 & $\mathrm{ND}$ & $\mathrm{ND}$ \\
72 & 14.6 & 12 & 6.9 & 26.0 & 6 & 1.5 \\
96 & 13.8 & 9 & 3.8 & 18.9 & 2 & 1.5 \\
\hline
\end{tabular}

Reaction conditions: $(R, S)$-ibuprofen $\left(66 \mathrm{mmol} \mathrm{L}^{-1}\right), 1$-propanol $\left(66 \mathrm{mmol} \mathrm{L}^{-1}\right)$, isooctane $(10 \mathrm{~mL})$, free lipase $(40 \mathrm{mg})$ or immobilized lipase $(0.24 \mathrm{~g})$ at $35^{\circ} \mathrm{C}$. ${ }^{\mathrm{a}} \mathrm{Conversion}$ is given as the percentage of initial racemic ibuprofen esterified after the reaction time; benantiomeric excess of the $(S)$-active ibuprofen; ${ }^{c}$ Value of enantioselectivity; ${ }^{\mathrm{d}}$ not detected.

These results revealed the different specific interactions between the enzyme active site and the substrate. During the adsorption (immobilization) process, the protein molecules (which are initially folded and able to contact the surface on only one side) begin to unfold following contact, thus creating multiple binding sites. ${ }^{18}$ This results in greater accessibility of immobilized lipase by the substrate molecules than that achieved by the free lipase and, consequently, greater esterification activity in the immobilized system. Moreover, in an anhydrous organic medium, there is no place for the enzyme to escape from the Celite, since the environment has low water content. Therefore, the esterification activity of the enzyme is well preserved..$^{19}$ According to Petkar et al..${ }^{20}$ these immobilized lipase preparations, when used in anhydrous media, become partially activated by direct interaction with organic solvents of an appropriate $\log P$ value and can be efficiently used for ester synthesis.

Conversely, data from this study demonstrate that the immobilized lipase displayed poor enantioselectivity, since it catalyzed the esterification of both $R$ - and $S$-enantiomers (enantiomeric excess of (S)-ibuprofen of 6\% after $72 \mathrm{~h}$ ).

Ikeda and Kurokawa ${ }^{21}$ reported the loss of activity of Candida rugosa lipase immobilized on cellulose acetatetitanium iso-propoxide, when compared with free lipase for the resolution of $(R, S)$-ibuprofen. This occurred as a consequence of the lipase being entrapped deeply in the gel, where the substrate is less accessible and does not contribute to the reaction..$^{21}$

Different strategies have been reported in the previous studies of our research group to improve the enantioselectivity of this lipase, such as the use of ionic liquids $^{7}$ and optimization of reaction medium. ${ }^{2}$ After optimization of several reaction conditions (type and ratios of isooctane/ionic liquid, amount of enzyme and reaction time), the $E$-value of Aspergillus niger lipase $(15 \%, \mathrm{~m} / \mathrm{v})$ could be duplicated $(E=9.2)$ in a solvent system composed of $[\mathrm{BMIM}]\left[\mathrm{PF}_{6}\right]$ and isooctane $(1: 1)$ after $96 \mathrm{~h}$ of reaction. ${ }^{7}$ These tests were performed using the crude free enzyme lyophilized extract in higher concentrations than those used in the current study. This is the first report to employ the native Aspergillus niger lipase immobilized on Celite.

\section{Reuse and storage stability of free and immobilized lipases used for the resolution of $(R, S)$-ibuprofen}

For large-scale applications of an enzyme, reusability is crucial in terms of process economy. Immobilized lipase was used repeatedly in the esterification of racemic ibuprofen and the performance was examined. The immobilized lipase was lyophilized overnight to remove the attached water and was reused with $0.2-0.3 \%(\mathrm{~m} / \mathrm{m})$ of residual water. The residual esterification activity of the free and the immobilized lipase after repeated use is shown in Figure 5. For the first 2 reuses, no obvious loss of immobilized lipase activity was observed. After 4 reuses the loss of activity was just $10 \%$. After 6 reuses, immobilized lipase retained $70 \%$ residual esterification activity against $18 \%$ for free lipase. 
Since water is produced during the esterification reaction, some molecules of enzyme may be desorbed from the solid support, leading to a decrease of activity with increased recycling number.

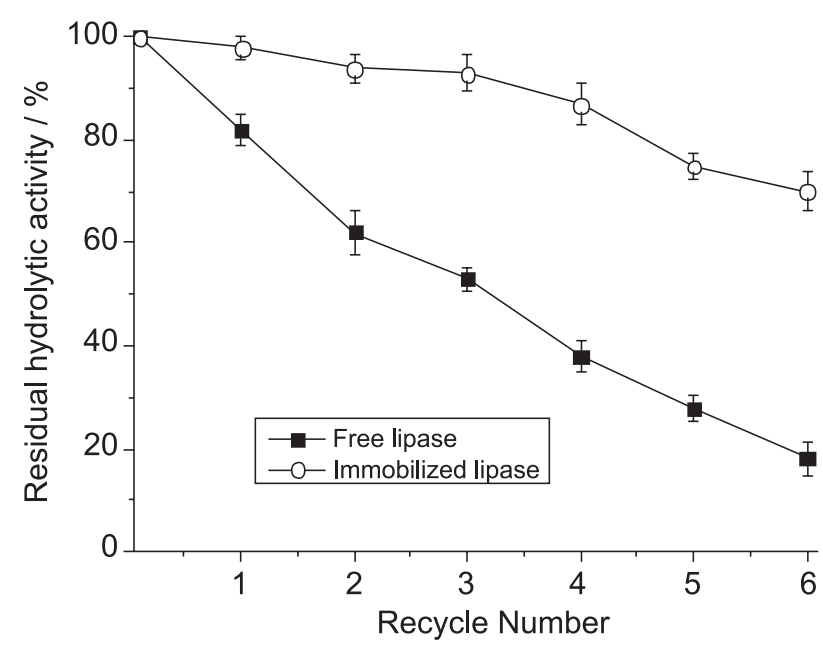

Figure 5. Recycles of immobilized and free Aspergillus niger lipases and residual esterification activity.

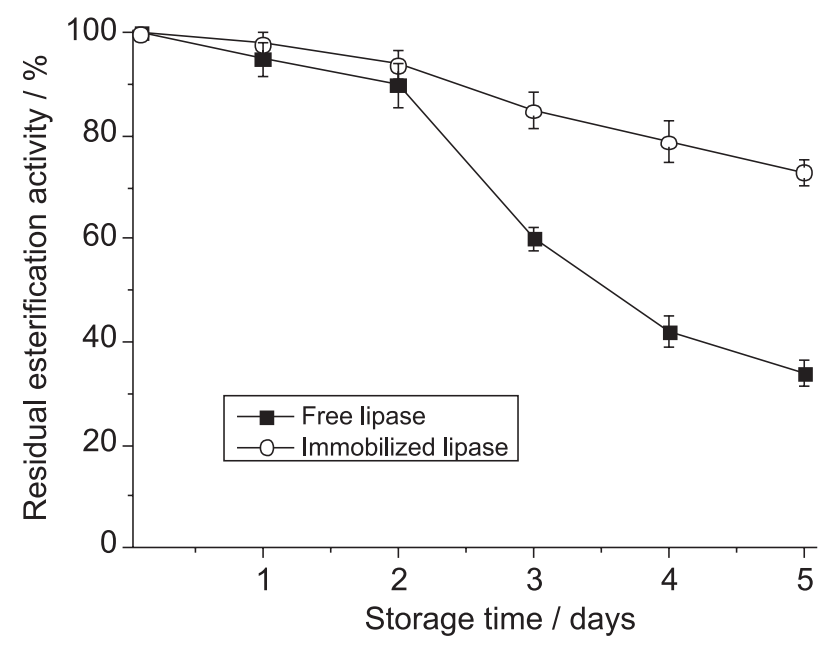

Figure 6. Storage time of immobilized and free Aspergillus niger lipases and residual esterification activity.

The storage stability of the immobilized lipase, compared with that of the free lipase, is shown in Figure 6. After 5 days of storage at $40^{\circ} \mathrm{C}$, the residual esterification activity of the immobilized lipase was $73 \%$, while that of the free lipase was $34 \%$, indicating that the immobilization procedure considerably increased the storage stability. Due to the low values obtained for enatiomeric excess and the $E$ values, these data were not plotted in Figures 5 and 6.

\section{Conclusions}

This study was carried out to compare the hydrolytic and esterification activities of four Aspergillus strain lipase producers. It may be concluded that $A$. niger lipase has a higher ability to esterify ibuprofen acid and this ability was amplified after immobilization by adsorption on Celite. Both the free and immobilized preparations displayed similar biochemical properties, and a significant improvement in the thermal stability of this immobilized enzyme compared to the native form was observed. The immobilization on Celite seems to play an important role in the stabilization of the enzymatic protein conformation and its resistance to thermal denaturation. Unfortunately, the enantioselectivity was decreased by the immobilization process under these assay conditions. The optimization of the process, as well as the study of other supports, will be further studied in order to improve the resolution of racemic ibuprofen.

\section{Acknowledgments}

We acknowledge financial support from the following Brazilian Funding Agency: Fundação de Amparo a Pesquisa do Estado de São Paulo (FAPESP) and from the Universidade São Francisco (USF).

\section{References}

1. Carvalho, P. O.; Contesini, F. J.; Ikegaki, M.; Braz. J. Microbiol. 2006, 37, 329.

2. Carvalho, P. O.; Contesini, F. J.; Bizaco, R.; Calafatti, S. A.; Macedo, G. A.; J. Ind. Microbiol. Biotechnol. 2006, 33, 713.

3. Gotor-Fernandéz, V.; Brieva, R.; Gotor, V.; J. Mol. Catal. B: Enzym. 2006, 40, 111.

4. Ghanem, A.; Tetrahedron 2007, 63, 1721.

5. Iwai, M.; Tsujisaka, Y. In Lipases; Borgstrom, B.; Brockman H. L., eds.; Elsevier: Amsterdam, 1984, pp. 443-469.

6. Carvalho, P. O.; Contesini, F. J.; Bizaco, R.; Macedo, G. A.; Food Biotechnol. 2005, 19, 183.

7. Contesini, F. J.; Carvalho, P. O.; Tetrahedron: Asymmetry 2006, 17, 2069.

8. Salah, R. B.; Ghamghui, H.; Miled, N.; Mejdoub, H.; Gargouri, Y.; J. Biosci. Bioeng. 2007, 103, 368.

9. Thomson, C. A.; Delaquis, P. J.; Mazza, G.; Crit. Rev. Food Sci. Nutr. 1999, 39, 165.

10. Lowry, O. H.; Rosenbrough, N. J.; Farr, A. L.; Randall, R. J.; J. Biol. Chem. 1951, 193, 265.

11. Chen, C. S.; Fujimoto, Y.; Girdaukas, G.; Sih, C. J.; J. Am. Chem. Soc. 1982, 104, 7294.

12. Noureddini, H.; Gao, X.; Joshi, S.; J. Am. Chem. Soc. 2003, 80, 1077. 
13. Sánchez, A.; Valero, F.; Lafuente, J.; Solà, C.; Biotechnol. Lett. 1998, 20, 1145 .

14. Toida, J.; Arikawa, Y.; Kondou, K.; Fukuzawa, M.; Sekiguchi, J.; Biosci., Biotechnol., Biochem. 1998, 62, 759.

15. Shu, Z-Y.; Yang, J-K.; Yan, Y-J.; Chin. J. Biotech. 2007, 23, 96.

16. Kierstan, M. P. J.; Coughlan, M.P. In Protein Immobilization: Fundamentals and Applications; Taylor, R. F., eds.; Marcel Dekker: New York, 1991, p. 13.
17. Freitas, L.; Perez, V. H.; Santos, J. C., de Castro, H. F.; J. Braz. Chem. Soc. 2007, 18, 1360.

18. Bohnert, J. L.; Horbett, T. A.; J. Colloid Interface Sci. 1986, 111,363 .

19. Zhou, R.; Xu, J-H.; Biochem. Eng. J. 2005, 23, 11.

20. Petkar, M.; Laili, A.; Caimi, P.; Daminati, M; J. Mol. Catal. B: Enzym. 2006, 39, 83.

21. Ikeda, Y.; Kurokawa, Y.; J. Biosci. Bioeng. 2002, 93, 98.

Received: February 19, 2008

Web Release Date: September 10, 2008

FAPESP helped in meeting the publication costs of this article. 